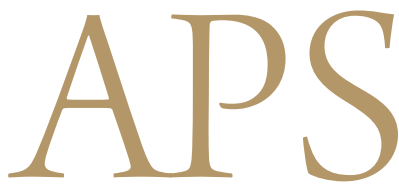

Archives of Plastic Surgery

\title{
Reducing Donor Site Morbidity When Reconstructing the Nipple Using a Composite Nipple Graft
}

\author{
Taik Jong Lee, Hyung Joo Noh, Eun Key Kim, Jin Sup Eom \\ Department of Plastic Surgery, Asan Medical Center, University of Ulsan College of Medicine, Seoul, Korea
}

\begin{abstract}
Background Numerous procedures are available for nipple reconstruction without a single gold standard. This study presents a method for reducing donor-site morbidity in nipple reconstruction using a composite nipple graft after transverse rectus abdominis musculocutaneous flap breast reconstruction.

Methods Thirty-five patients who underwent nipple reconstruction using a composite nipple graft technique between July of 2001 and December of 2009 were enrolled in this study. To reduce the donor site morbidity, the superior or superior-medial half dome harvesting technique was applied preserving the lateral cutaneous branch of the fourth intercostal nerves. The patients were asked to complete a previously validated survey to rate the color and projection of both nipples, along with the sensation and contractility of the donor nipple; and whether, in retrospect, they would undergo the procedure again. To compare projection, we performed a retrospective chart review of all the identifiable patients who underwent nipple reconstruction using the modified top hat flap technique by the same surgeon and during the same period.

Results Thirty-five patients were identified who underwent nipple reconstruction using a composite nipple graft. Of those, 29 patients (82.9\%) responded to the survey. Overall, we received favorable responses to the donor site morbidity. Projection at postoperative 6 months and 1 year was compared with the immediate postoperative results, as well as with the results of nipples reconstructed using the modified top hat flap.

Conclusions The technique used to harvest donor tissue is important. Preserving innervation of the nipple while harvesting can reduce donor site morbidity.
\end{abstract}

Keywords Morbidity / Nipples / Reconstructive surgical procedures
Correspondence: Taik Jong Lee Department of Plastic Surgery, Asan Medical Center, University of Ulsan College of Medicine, 88 Olympic-ro 43-gil, Songpa-gu,

Seoul 138-736, Korea

Tel: +82-2-3010-3600

Fax: +82-2-476-7471

E-mail: tjlee@amc.seoul.kr

Received: 5 Apr 2012 • Revised: 16 May 2012 • Accepted: 31 May 2012

pISSN: 2234-6163 • elSSN: 2234-6171 • http://dx.doi.org/10.5999/aps.2012.39.4.384• Arch Plast Surg 2012;39:384-389

\section{INTRODUCTION}

As the nipple is an important part of the breast, the presence of a nipple is psychologically critical for many women who have had a mastectomy [1]. Patients who also undergo nipple-areola complex reconstruction are more satisfied with the reconstruc- tion than patients who do not undergo the procedure $[1,2]$.

Numerous techniques for reconstructing the nipple-areola complex have been proposed for decades [3-14]. This fact supports the notion that achieving consistent quality nipple reconstruction still remains a challenge. There have been numerous studies focusing on the projection of the reconstructed nipple,

Copyright $\odot 2012$ The Korean Society of Plastic and Reconstructive Surgeons

This is an Open Access article distributed under the terms of the Creative Commons Attribution Non-Commercial License (http://creativecommons.org/

licenses/by-nc/3.0/) which permits unrestricted non-commercial use, distribution, and reproduction in any medium, provided the original work is properly cited.

www.e-aps.org 
evaluating the local flaps versus the composite nipple graft [15]. Shestak et al. [16] reported loss of projection from $20 \%$ to $74 \%$ over the first 6 months after surgery with three commonly used flap techniques.

Composite nipple graft is feasible when the patient has large nipples. No other technique produces a reconstructed nipple that can so closely match the contralateral nipple in color, shape, texture, and long-term projection. However, plastic surgeons remain reluctant to use the contralateral nipple as a donor site. The roots of this reluctance are based on concerns of causing morbidity such as pain, numbness, and scarring, and on the fears of emotional pain caused by "unnecessary" surgery on the normal breast. We investigated the donor-site morbidity and patient satisfaction of composite nipple grafts, and compared the maintenance of projection with nipples reconstructed using the modified top hat flap after transverse rectus abdominis musculocutaneous (TRAM) flap breast reconstruction had been performed.

\section{METHODS}

A retrospective chart review of all of the identifiable patients who underwent composite nipple grafts by the senior author (TJ Lee) between July of 2001 and December of 2009 was performed.

\section{Surgical procedure}

For patients who underwent mastectomy with resection of the nipple and had a contralateral breast with an intact nipple, a composite nipple graft was recommended if the patient had a sufficiently large nipple. A large nipple is considered and indicated when the size of the nipple is larger than $1.5 \mathrm{~cm}$ in diameter, has projects at least $8 \mathrm{~mm}$, and the patient herself wants a reduction of the nipple. Contraindications included the patient intended future pregnancy or breast-feeding. If the patient refused the operation or the size of the nipple was less than $1.5 \mathrm{~cm}$ in diameter and $8 \mathrm{~mm}$ in projection, alternative reconstruction techniques were recommended. After confirming the adequate nipple size for the procedure, 50\% of the existing nipple was marked for harvesting while the nipple was in the erect state. Considering the innervation of the nipple-areola complex, the superior or superior-medial-half dome harvesting technique was applied while sparing the lateral cutaneous branch of the 4th intercostal nerve (Fig. 1). The tiny pinpoint bleeding was not coagulated after deepithelization of the recipient site. The composite nipple graft was sutured to the deepithelialized recipient site using a simple interrupted suture and bolster dressing. The donor nipple was closed using a simple interrupted suture (Fig. 2). The reconstruction of the areola was performed by tattooing 2 months later.

\section{Data analysis}

The 35 patients who underwent nipple reconstruction using composite nipple grafts were asked to complete previously validated BREAST-Q surveys to rate the color and projection of both nipples, the nipple sensation and contractility, sexual attractiveness of the donor nipple, and whether the patient would, in retrospect, undergo the procedure again if she could go back in time (Fig. 3) [17]. Patients were questioned on both the reconstructed nipple results and donor site morbidity. The donor site questions included the patient's satisfaction with the donor nipple's sensation, contractility, sexuality and sexual arousal. Responses to the questionnaire were solicited by telephone or in person.

For comparison of projection, a retrospective chart review of all identifiable patients who underwent nipple reconstruction using the modified top hat flap performed by the same surgeon during the same period was performed [18-21]. Between July

\section{Fig. 1. Pre- and postoperative figures}

(A) Preoperative incision line, frontal view. (B) Preoperative incision line, lateral view. (C) Postoperative figure, frontal view.

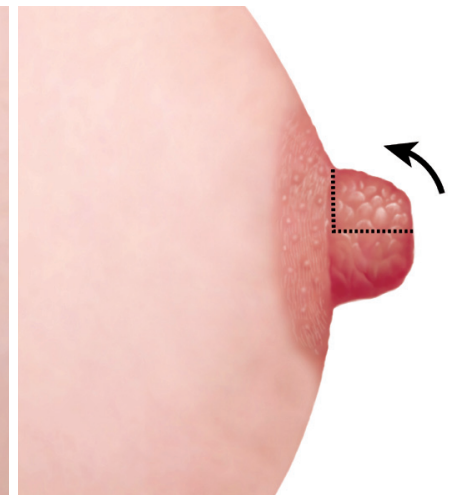




\section{Fig. 2. Pre- and postoperative view of a patient}

(A) Preoperative photo, frontal view of the incision line, donor site. (B) Preoperative photo, superior-oblique view of the incision line, donor site. (C) Postoperative photo, frontal view of the donor site after primary closure. (D) Postoperative photo, superior-oblique view of the donor site after primary closure. (E) Preoperative photo, frontal view of the recipient site after deepithelialization. (F) Postoperative photo, frontal view of the recipient site after the composite nipple was utured.
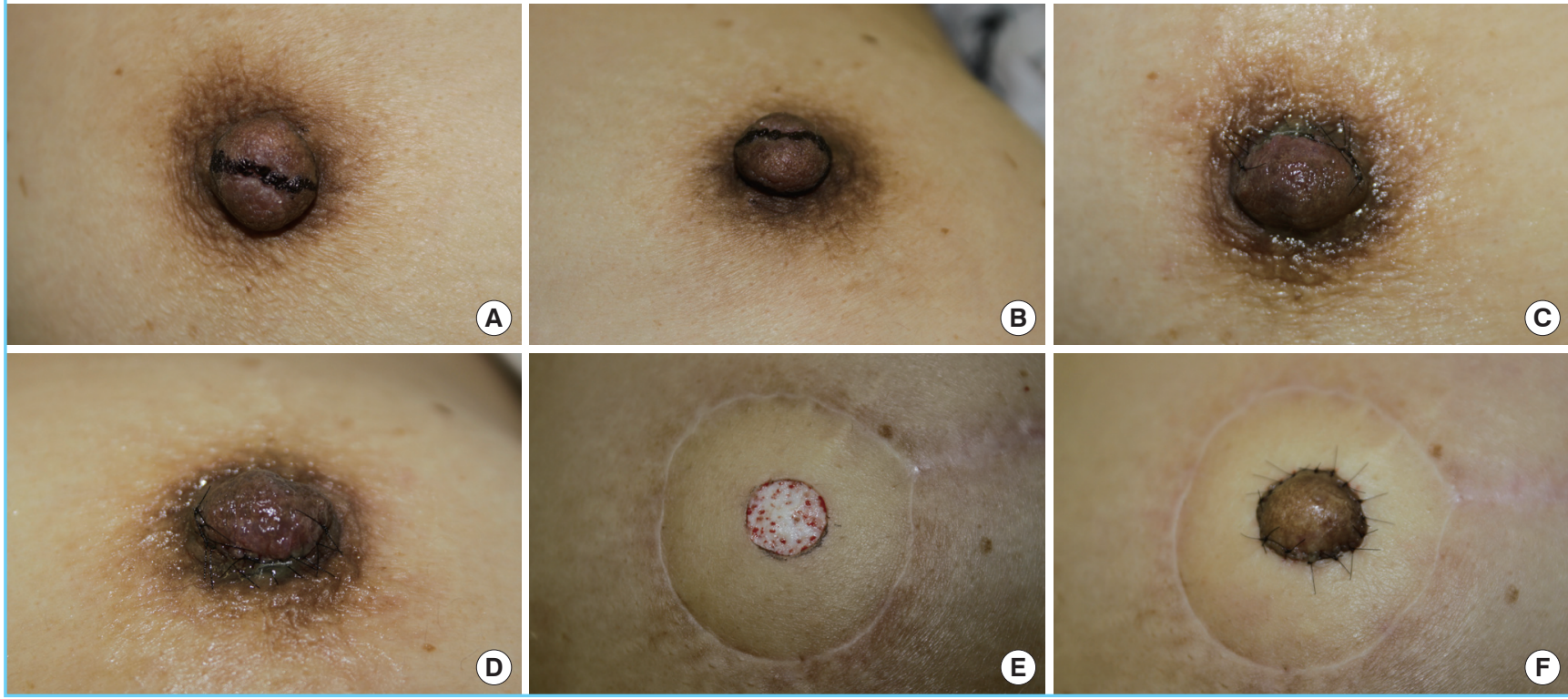

\section{Fig. 3. Questionnaire}

Survey derived from the BREAST-Q Survey to assess donor site morbidity and patient satisfaction (From Spear et al., with permission from American Society of Plastic Surgeons [21]).

\begin{tabular}{|c|c|c|c|c|}
\hline & $\begin{array}{c}\text { Very } \\
\text { Dissatisfied }\end{array}$ & $\begin{array}{c}\text { Somewhat } \\
\text { Dissatisfied }\end{array}$ & $\begin{array}{l}\text { Somewhat } \\
\text { Satisfied }\end{array}$ & $\begin{array}{l}\text { Very } \\
\text { Satisfied }\end{array}$ \\
\hline $\begin{array}{l}\text { a. How your reconstructed nipple } \\
\text { looks? }\end{array}$ & 1 & 2 & 3 & 4 \\
\hline $\begin{array}{l}\text { b. How natural your reconstructed } \\
\text { nipple looks? }\end{array}$ & 1 & 2 & 3 & 4 \\
\hline $\begin{array}{l}\text { c. The color of your reconstructed } \\
\text { nipple? }\end{array}$ & 1 & 2 & 3 & 4 \\
\hline $\begin{array}{l}\text { d. The height (projection) of your } \\
\text { reconstructed nipple? }\end{array}$ & 1 & 2 & 3 & 4 \\
\hline $\begin{array}{l}\text { e. How your reconstructed areola } \\
\text { looks? }\end{array}$ & 1 & 2 & 3 & 4 \\
\hline $\begin{array}{l}\text { f. The color of your reconstructed } \\
\text { areola? }\end{array}$ & 1 & 2 & 3 & 4 \\
\hline
\end{tabular}

2. Compared to before you composite nipple graft, now is your donor nipple (not the reconstructed nipple)

\begin{tabular}{|c|c|c|c|c|}
\hline & 1 & 2 & 3 & 4 \\
\hline a. Sensation? & Totally numb & $\begin{array}{l}\text { Much less } \\
\text { sensation than } \\
\text { before surgery }\end{array}$ & $\begin{array}{l}\text { Somewhat less } \\
\text { sensation than } \\
\text { before surgery }\end{array}$ & $\begin{array}{c}\text { Sensation } \\
\text { unchanged } \\
\text { from before } \\
\text { surgery }\end{array}$ \\
\hline b. Contractility? & Never contracts & $\begin{array}{l}\text { Contracts with } \\
\text { vigorous } \\
\text { stimulation }\end{array}$ & $\begin{array}{c}\text { Contracts with } \\
\text { moderate } \\
\text { stimulation }\end{array}$ & $\begin{array}{l}\text { Contracts with } \\
\text { normal } \\
\text { sensation }\end{array}$ \\
\hline c. Projection? (height) & Way too small & $\begin{array}{l}\text { Somewhat } \\
\text { small }\end{array}$ & $\begin{array}{l}\text { Al little too } \\
\text { small }\end{array}$ & Adequate \\
\hline $\begin{array}{l}\text { d. Did your donor nipple contribute } \\
\text { greatly to your feeling of femininity } \\
\text { / sexuality before surgery? }\end{array}$ & Not at all & A little bit & Somewhat & Greatly \\
\hline $\begin{array}{l}\text { e. Has the contribution of your } \\
\text { donor rinple to your feeling of } \\
\text { femininity / sexuality changed? }\end{array}$ & $\begin{array}{c}\text { Greatly } \\
\text { decrease role }\end{array}$ & $\begin{array}{l}\text { Somewhat } \\
\text { decreased role }\end{array}$ & $\begin{array}{l}\text { Slightly } \\
\text { decreased role }\end{array}$ & $\begin{array}{l}\text { Unchanged } \\
\text { role }\end{array}$ \\
\hline $\begin{array}{l}\text { f. Was your donor nipple sensation } \\
\text { a large contributor to sexual } \\
\text { arousal before surgery? }\end{array}$ & Notat all & A little bit & Somewhat & Greatly \\
\hline $\begin{array}{l}\text { g. Has the role of your donor } \\
\text { nipple in sexual arousal changed? }\end{array}$ & $\begin{array}{c}\text { Greatly } \\
\text { decrease role }\end{array}$ & $\begin{array}{l}\text { Somewhat } \\
\text { decreased role }\end{array}$ & $\begin{array}{l}\text { Slightly } \\
\text { decreased role }\end{array}$ & $\begin{array}{l}\text { Unchanged } \\
\text { role }\end{array}$ \\
\hline $\begin{array}{l}\text { n. If you could go back in time, } \\
\text { would you have this procedure } \\
\text { performed again? }\end{array}$ & Definitely not & Probably not & Probably & Definitely \\
\hline
\end{tabular}

of 2001 and December of 2009, 272 patients underwent nipple reconstructions using the modified top hat flap. Projection of the neo-nipple was measured with a caliper 6 months and 1 year after reconstruction and compared with the immediate postoperative value using the Wilcoxon signed-rank test within each technique. Significance levels were determined using the Bonferroni correction for multiple comparisons $(\mathrm{P}<0.05 / 2)$. The Mann-Whitney $\mathrm{U}$ test was used to compare the results of the modified top hat flap group and composite nipple graft group. All tests were two sided, and $\mathrm{P}<0.05$ was considered statistically significant.

\section{RESULTS}

\section{Patients' satisfaction and donor-site morbidities}

Among all of the patients who underwent TRAM flap breast reconstruction between July 2001 and December 2009, 35 patients were identified who underwent nipple reconstruction using a composite nipple graft; 29 out of the 35 (83\%) completed the survey. Of the 29,20 underwent immediate breast reconstruction and 9 underwent delayed breast reconstruction.

When asked about the reconstructed nipple, $51.7 \%$ of the patients responded that they were somewhat or very satisfied with the appearance of the reconstructed nipple, $51.7 \%$ indicated they were somewhat or very satisfied with the naturalness of the nipple, $58.6 \%$ indicated they were somewhat or very satis- 
fied with the color of the nipple, and $48.2 \%$ indicated they were somewhat or very satisfied with the projection of the nipple (Fig. 4). When asked about the donor nipple, $89.7 \%$ of the patients indicated that the sensation of the donor nipple had decreased only somewhat or not at all, $86.2 \%$ indicated that the donor nip-
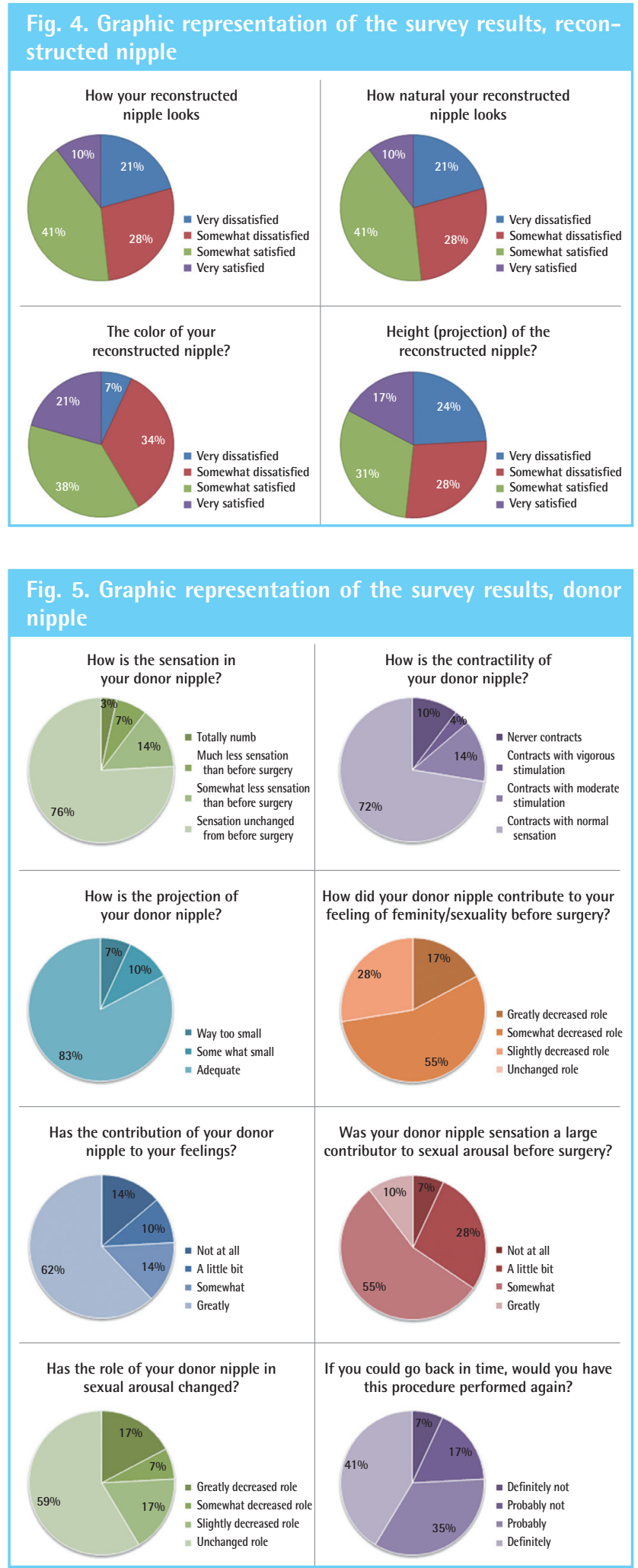

ple had normal or nearly normal contraction, $83 \%$ indicated that the donor nipple had almost adequate or adequate projection, and $75.8 \%$ of responders indicated the role of the donor nipple in their femininity or sexuality was only slightly decreased or unchanged after surgery; and $75.9 \%$ indicated that they would probably or definitely undergo this procedure again (Fig. 5).

\section{Maintenance of projection}

All of the grafts and flaps survived except in 2 cases of superficial necrosis of the composite graft. The average initial projection was $6.41 \mathrm{~mm}$ in the composite graft group and $9.46 \mathrm{~mm}$ in the modified top hat flap group. The average projection after 6 months was $4 \mathrm{~mm}$ ( $68 \%$ of the initial projection) in the composite nipple graft group and $4.66 \mathrm{~mm}$ (49\% of the initial projection) in the modified top hat flap group $(\mathrm{P}=0.001)$, and the average projection after 1 year was $4.08 \mathrm{~mm}(61 \%)$ and $4.01 \mathrm{~mm}(42 \%)$, respectively $(\mathrm{P}<0.001)$ (Table 1, Fig. 6).

\section{DISCUSSION}

A stable projecting nipple mound with the size, shape, color, and texture similar to the contralateral nipple is an important criterion for successful breast reconstruction. In cases of unilat-

\begin{tabular}{|c|c|c|}
\hline & $\begin{array}{l}\text { Modified top hat flap } \\
\qquad(\mathrm{n}=272)\end{array}$ & $\begin{array}{l}\text { Composite nipple } \\
\qquad(\mathrm{n}=17)\end{array}$ \\
\hline Initial & $9.46 \pm 1.67$ & $6.41 \pm 2.00$ \\
\hline $6 \mathrm{mo}$ & $4.66 \pm 2.12$ & $4.00 \pm 1.55$ \\
\hline $1 \mathrm{yr}$ & $4.01 \pm 1.60$ & $4.08 \pm 1.75$ \\
\hline 6 mo (\%) & $51 \pm 20$ & $32 \pm 25$ \\
\hline 1 yr (\%) & $58 \pm 15$ & $39 \pm 21$ \\
\hline
\end{tabular}

\section{Fig. 6. Comparison of projection}

Projection of the neo-nipple at 6 months and 1 year postoperatively.

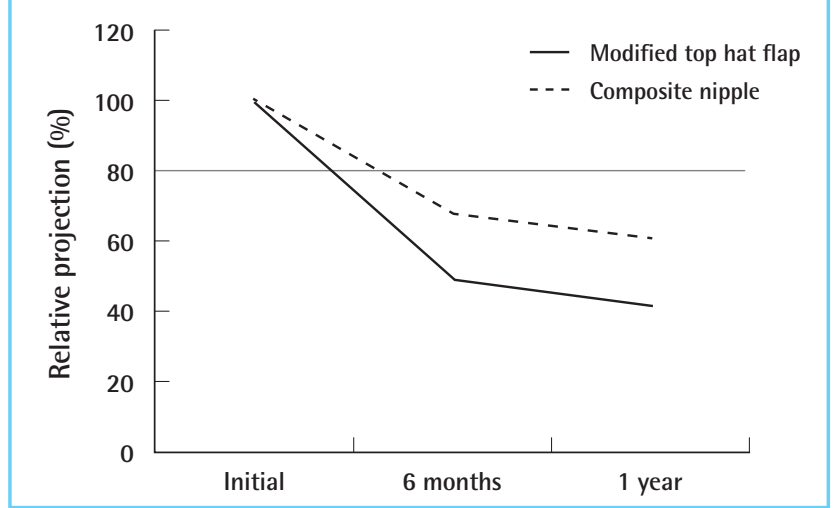


eral nipple reconstruction, the greatest challenge is matching the natural contralateral nipple in all aspects.

The goals of nipple reconstruction include the recreation of the nipple-areola complex using reliable, reproducible, and predictable methods while minimizing the number of procedures, inconvenience, and morbidity. Most nipple reconstructions fail to accomplish these goals. Even though the size and shape can be matched, the color, projection, and texture still may not match the natural nipple. A composite nipple graft can provide similar tissue of the correct color and texture. Most importantly, once the tissue is taken, the results are stable. However, some plastic surgeons have been reluctant to perform composite nipple grafts due to possible complications such as pain, numbness, disfigurement, and scarring of the donor nipple.

Spear et al. [21] reported on donor site morbidity. According to the report, $63 \%$ of patients indicated the sensation of the donor nipple had changed from before surgery, $73 \%$ indicated that the donor nipple had abnormal contraction, and $63 \%$ indicated the role of the donor nipple in sexual arousal had changed after surgery.

In our study, we focused on the donor site morbidity of the composite nipple grafts and compared the donor site morbidity of our results with those of Spear et al. (Fig. 7). The comparison revealed significant differences between the two studies: 34\% of our patients indicated the sensation of the donor nipple had changed from before surgery (63\%, Spear et al. [21]); $28 \%$ indicated that the donor nipple had abnormal contraction $(73 \%$, Spear et al. [21]); and $41 \%$ indicated the role of the donor nipple in sexual arousal had changed after surgery $(63 \%$, Spear et al. [21]).

We assume that the cause of these differences lay in the techniques used to harvest the donor nipple. Spear et al. [21] har-

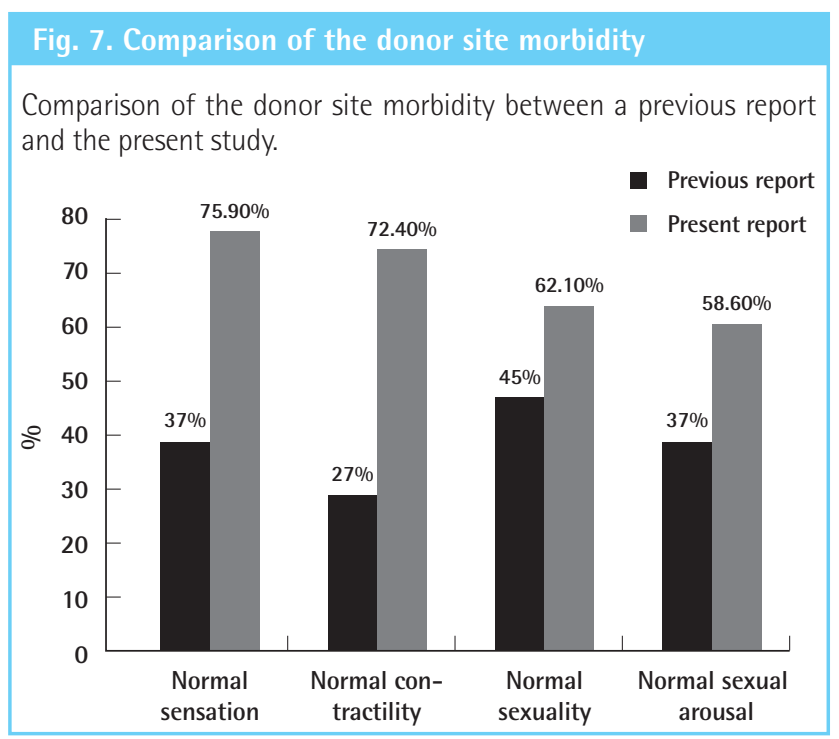

vested the nipple from the donor site with discretion in each case; we harvested the superior or superior-medial part of the nipple as a half-dome, conserving the lower lateral quadrant.

The nipple-areolar complex receives its main innervation from the lateral and anterior cutaneous branches of the second to the fifth intercostal nerves, which pass superficially, converging on the areola from all directions and passing underneath in the subdermal plane to reach the nipple [22-24]. The lateral cutaneous branch of the fourth intercostal nerve, which travels from lower lateral quadrant of the nipple, is the most important (Fig. 8). We believe that preserving the innervation is very important for preventing donor site morbidity.

We also assumed that technical differences also lay in the methods used for donor site closure. Spear et al. [21] often used pursestring sutures with 5-0 chromic sutures; we directly closed the donor site with simple interrupted 6-0 nylon sutures, which have better long-term scarring results.

Lee et al. [25] reported that the mean value of nipple height is $6.54 \pm 3.74 \mathrm{~mm}$ for Korean women. In our cases, the nipple height was similar to the mean value at the immediate postoperative time. We compared the late result of the differences in nipple projection between the two methods. The projection of the neo-nipple at 6 months was significantly reduced compared with the initial projection for the modified top hat flap and composite nipple graft groups. However, the projection of the nipple reconstructed using a composite nipple graft was significantly well maintained and more effective than the one reconstructed using the modified top hat flap technique. If the patient had sufficiently large nipples, the projection results would be more superior.

A composite nipple graft is simple to perform and provides good nipple size, shape, color, and texture. We found that well

\section{Fig. 8. The nerve innervations in the nipple and areola}

The main nerve innervations from the lateral cutaneous branch of the fourth intercostal nerve in the nipple and areola.

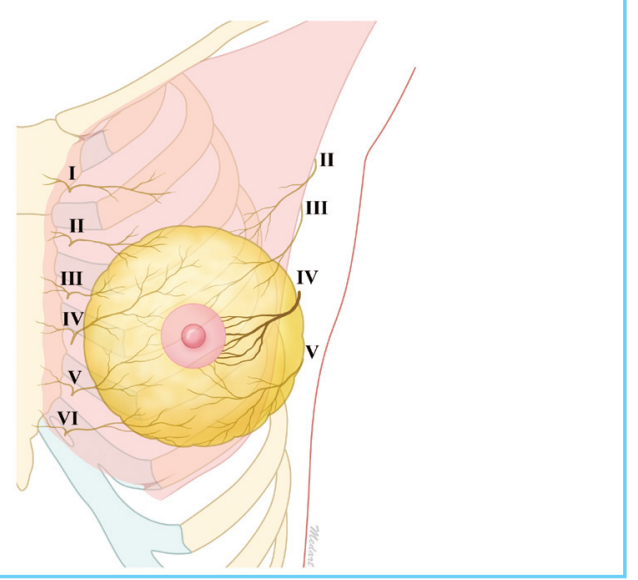


maintained nipple projection is another advantage of this technique. Patient satisfaction in our study was generally high and most of the patients stated that they would undergo the procedure again if they were to do it all over again. Although the benefits and risks should be discussed with each patient, we believe the benefits of a composite nipple graft outweigh the risks if the donor tissue is harvested with a proper technique that preserves the innervation.

\section{REFERENCES}

1. Wellisch DK, Schain WS, Noone RB, et al. The psychological contribution of nipple addition in breast reconstruction. Plast Reconstr Surg 1987;80:699-704.

2. Asplund O. Nipple and areola reconstruction. A study in 79 mastectomized women. Scand J Plast Reconstr Surg 1983; 17:233-40.

3. Gruber RP. Nipple-areola reconstruction: a review of techniques. Clin Plast Surg 1979;6:71-83.

4. Losken A, Mackay GJ, Bostwick J. Nipple reconstruction using the C-V flap technique: a long-term evaluation. Plast Reconstr Surg 2001;108:361-9.

5. Weiss J, Herman O, Rosenberg L, et al. The S nipple-areola reconstruction. Plast Reconstr Surg 1989;83:904-6.

6. Eng JS. Bell flap nipple reconstruction: a new wrinkle. Ann Plast Surg 1996;36:485-8.

7. Tanabe HY, Tai Y, Kiyokawa K, et al. Nipple-areola reconstruction with a dermal-fat flap and rolled auricular cartilage. Plast Reconstr Surg 1997;100:431-8.

8. Chang WH. Nipple reconstruction with a T flap. Plast Reconstr Surg 1984;73:140-3.

9. Anton M, Eskenazi LB, Hartrampf CR. Nipple reconstruction with local flaps: star and wrap around flaps. Perspect Plast Surg 1991;5:67-78.

10. Kroll SS. Nipple reconstruction with the double-opposing tab flap. Plast Reconstr Surg 1999;104:511-4.

11. Little JW, Spear S. Nipple-areolar reconstruction. Perspect Plast Surg 1988;2:1-12.

12. Brent B, Bostwick J. Nipple-areola reconstruction with au- ricular tissues. Plast Reconstr Surg 1977;60:353-61.

13. Hallock GG. Polyurethane nipple prosthesis. Ann Plast Surg 1990;24:80-5.

14. Cao YL, Lach E, Kim TH, et al. Tissue-engineered nipple reconstruction. Plast Reconstr Surg 1998;102:2293-8.

15. Few JW, Marcus JR, Casas LA, et al. Long-term predictable nipple projection following reconstruction. Plast Reconstr Surg 1999; 104:1321-4.

16. Shestak KC, Gabriel A, Landecker A, et al. Assessment of long-term nipple projection: a comparison of three techniques. Plast Reconstr Surg 2002;110:780-6.

17. Pusic AL, Klassen AF, Scott AM, et al. Development of a new patient-reported outcome measure for breast surgery: the BREAST-Q. Plast Reconstr Surg 2009; 124:345-53.

18. Cheng MH, Ho-Asjoe M, Wei FC, et al. Nipple reconstruction in Asian females using banked cartilage graft and modified top hat flap. Br J Plast Surg 2003;56:692-4.

19. Hamori CA, LaRossa D. The top hat flap: for one stage reconstruction of a prominent nipple. Aesthetic Plast Surg 1998;22:142-4.

20. Cheng MH, Rodriguez ED, Smartt JM, et al. Nipple reconstruction using the modified top hat flap with banked costal cartilage graft: long-term follow-up in 58 patients. Ann Plast Surg 2007;59:621-8.

21. Spear SL, Schaffner AD, Jespersen MR, et al. Donor-site morbidity and patient satisfaction using a composite nipple graft for unilateral nipple reconstruction in the radiated and nonradiated breast. Plast Reconstr Surg 2011;127:1437-46.

22. Sarhadi NS, Shaw Dunn J, Lee FD, et al. An anatomical study of the nerve supply of the breast, including the nipple and areola. Br J Plast Surg 1996;49:156-64.

23. Jaspars JJ, Posma AN, van Immerseel AA, et al. The cutaneous innervation of the female breast and nipple-areola complex: implications for surgery. Br J Plast Surg 1997;50:249-59.

24. Farina MA, Newby BG, Alani HM. Innervation of the nipple-areola complex. Plast Reconstr Surg 1980;66:497-501.

25. Lee JH, Yang JD, Chung KH, et al. Anthropometric measurement for the nipple areola complex. J Korean Soc Plast Reconstr Surg 2008;35:461-4. 